Original Article

\title{
How omnivory affects the survival and choices of earwig Doru luteipes (Scudder) (Dermaptera: Forficulidae)?
}

\author{
Como a onivoria afeta a sobrevivência e escolhas da tesourinha Doru luteipes (Scudder) \\ (Dermaptera: Forficulidae)?
}

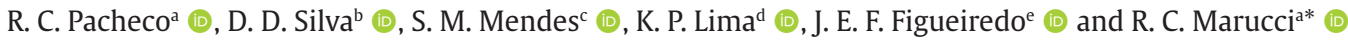 \\ aUniversidade Federal de Lavras - UFLA, Laboratório de Controle Biológico de Pragas, Lavras, MG, Brasil \\ ${ }^{\mathrm{b} E m b r a p a}$ Milho e Sorgo, Laboratório de Fitopatologia, Sete Lagoas, MG, Brasil \\ ‘Embrapa Milho e Sorgo, Laboratório de Entomologia, Sete Lagoas, MG, Brasil \\ dUniversidade Federal de Lavras - UFLA, Departamento de Estatística, Lavras, MG, Brasil \\ eEmbrapa Milho e Sorgo, Laboratório de Bioquímica e Biologia Molecular, Sete Lagoas, MG, Brasil
}

\begin{abstract}
Doru luteipes (Scudder, 1876) is an omnivorous predator that finds different food resources in the corn plant: eggs of Spodoptera frugiperda (J.E. Smith, 1797), uredospores of Puccinia polysora (Underw, 1897), and pollen. Knowing the survival and food preferences of this predator is essential to define its relevance as a biological control agent. We hypothesize that the foraging behavior and predatory capacity of $D$. luteipes may be affected when several food resources, especially eggs of $S$. frugiperda, uredospores of $P$. polysora, and pollen are concurrently in the same plant. The survival of $D$. luteipes in the nymph stage and their preference among food resources, often available in corn plants, were determined. To verify the survival of $D$. luteipes, newly hatched nymphs were fed exclusively with 1- uredospores of P. polysora, 2- eggs of S. frugiperda, 3- corn pollen, 4- a combination of uredospores + eggs, and 5- artificial diet (control). In another experiment, nymphs and adults of $D$. luteipes with 24 and 48 hours of fasting were individually released in the center of a container with four diets: 1 - uredospores of $P$. polysora, 2- eggs of $S$. frugiperda, 3- corn pollen, 4- artificial diet, and maintained for 10 minutes, to evaluate the food choice and feeding time. The exclusive feeding with S. frugiperda eggs caused low nymph survival (8\%), but the combination of $P$. polysora uredospores $+S$. frugiperda eggs allowed $58.3 \%$ survival. $D$. luteipes preferred feeding during the nighttime and the most significant proportions of choices by nymphs and adults were for pollen and diet, with adults spending more time eating pollen. These findings indicate that the trophic choices of $D$. luteipes are relevant to understand its contribution as an agent to control pest insects and fungal diseases in corn.
\end{abstract}

Keywords: Zea mays, Spodoptera frugiperda, Puccinia polysora, biological control.

\begin{abstract}
Resumo
Doru luteipes (Scudder, 1876) é um predador onívoro, que encontra na planta do milho diferentes recursos alimentares: ovos de Spodoptera frugiperda (J.E. Smith, 1797), uredósporos de Puccinia polysora (Underw, 1897) e pólen. Para definição da relevância desse predador como agente de controle biológico, conhecer a sobrevivência e preferência alimentar é essencial. Nós hipotetizamos que o comportamento de forrageamento e a capacidade de predação de $D$. luteipes podem ser afetados quando uma mesma planta oferece ovos, uredósporos e pólen, concomitantemente. A sobrevivência de $D$. luteipes na fase de ninfa e sua preferência entre os recursos alimentares, frequentemente disponíveis nas plantas de milho, foram determinados. Para verificar a sobrevivência de $D$. luteipes, ninfas recém eclodidas foram alimentadas exclusivamente com 1- uredósporos de P. polysora, 2- ovos de S. frugiperda, 3- pólen de milho, 4- combinação de uredósporos + ovos e 5- dieta artificial (controle). Em outro experimento, ninfas e adultos de $D$. luteipes com 24 e 48 horas de jejum foram liberadas individualmente, em recipientes contendo quatro dietas: 1- uredósporos de P. polysora, 2- ovos de S. frugiperda, 3- pólen de milho, 4- dieta artificial e mantidas durante $10 \mathrm{~min}$, sendo avaliados a escolha pelo alimento e o tempo de alimentação. A alimentação exclusiva com ovos de S. frugiperda ocasionou baixa sobrevivência das ninfas (8\%), porém a combinação de uredósporos de P. polysora + ovos de S. frugiperda possibilitou sobrevivência de 58,3\%. D. luteipes preferiu se alimentar durante o período noturno e as maiores proporções de escolhas das ninfas e dos adultos ocorreram no pólen e na dieta, sendo que os adultos gastaram mais tempo se alimentando de pólen. Estas descobertas indicam que as escolhas tróficas de $D$. luteipes são relevantes para compreender sua contribuição como agente de controle de insetos-praga e doença fúngicas em milho.
\end{abstract}

Palavras-chave: Zea mays, Spodoptera frugiperda, Puccinia polysora, controle biológico.

*e-mail: rosangelac.marucci@ufla.br

Received: September 23, 2020 - Accepted: January 4, 2021 


\section{Introduction}

The common earwig Doru luteipes (Dermaptera, Forficulidae) is an omnivorous predator with cryptic and tigmotact habit hidden during the day, but active at night (Lamb and Wellington, 1975; Romero-Sueldo et al., 2010; Naranjo-Guevara et al., 2017). The corn plant is the preferred habitat for this species, as the cartridge and the ear provide a dark and damp shelter (Jarvis et al., 2005; Pasini et al., 2007; Naranjo-Guevara et al., 2017), and different food sources (Marucci et al., 2019).

The high predatory capacity (Romero-Sueldo and Virla, 2017; Souza et al., 2019) and a diversified diet consisting of insect eggs and prey at any developmental stage from different orders like Lepidoptera, Hemiptera, and Thysanoptera are one of the most significant attributes of D. luteipes (Bacci et al., 2001; Cruz, 2007; RomeroSueldo et al., 2014; Silva, 2019).

Doru luteipes also feed on corn pollen, which provides increased survival and fertility (Marucci et al., 2019). However, according to Schuldiner-Harpaz and Coll (2017), plants providing a dietary supplement to omnivorous predators can influence biological control in two ways: i) by increasing the predator populations or ii) reducing the prey consumption. Thus, it is necessary to understand the possible interactions among the food sources to enhance the use of earwig as a biological control agent against insects-pests in corn culture.

The omnivorous habit of $D$. luteipes is important to its maintenance throughout the corn growing season, helping controlling pests such as Spodoptera frugiperda, Helicoverpa zea (Boddie, 1850) (Lepidoptera, Noctuidae) and other small arthropods. Also, many Dermaptera species, including $D$. luteipes, have been reported to have a mycophagous habit (Chen et al., 2014; Paula et al., 2016), which opens the possibility of exploring the mycophagous habit of the earwig to control pathogenic fungi of maize crop. Silva et al. (2022) proved the mycophagy of $D$. luteipes on uredospores of Puccinia polysora, the causative agent of southern corn rust, by detecting a large number of uredospores in the feces of the insect.

The polysora rust (Southern rust) is one of the most important diseases of maize in Brazil with hot tropical climates, where high humidity and temperature $\left(26^{\circ} \mathrm{C}\right.$ to $30{ }^{\circ} \mathrm{C}$ ) predominate (Shurtleff, 1992). The disease symptoms are characterized by circular to oval pustules, light brown to orange in color, distributed on the upper surface of the leaves (Dudienas et al., 2013). The spores or uredospores carried by wind and rain are the main factors for long-distance dispersal (Casela and Ferreira, 2002).

Understanding the complex trophic interactions of a potential biocontrol agent is crucial for defining and enhancing biological control strategies when using a generalist predator (Vankosky and VanLaerhoven, 2015). Many factors, such as prey availability, plant nutritional composition, the developmental stage, and health condition of the predator, directly influence the consumption of food and the choices of favorite prey (Coll, 1996). Considering D. luteipes, an omnivorous predator that exhibits mycophagous habit, these interactions become even more complicated. Since the earwig can consume pest insects and pathogenic fungi, these habits allows characterizing this species as a potential biological control agent with double occupation capacity.

Given the diversity of food resources available in the cornfields, we made the following questions: 1- Does eating only one type of food interfere in the development of the nymphs of $D$. luteipes? 2- Does the feeding schedule influence the food choices of the earwig? 3- Does food preference vary between the immature and adult stages of $D$. luteipes? 4- Does the diversity of food resources influence food consumption and the choices of favorite prey by $D$. luteipes? To answer these questions, we evaluated the survival of the early stages of $D$. luteipes and the food preference of nymphs and adults in a simulated corn crop environment with different food sources.

\section{Material and Methods}

\subsection{Obtaining insects and food sources}

The rearing of Doru luteipes was performed using acrylic cages coated with brown paper, kept in an air-conditioned room at $27 \pm 2{ }^{\circ} \mathrm{C}, 70 \pm 10 \%$ relative humidity ( $\left.R H\right)$, and $14 \mathrm{~h}$ of photophase. In each cage, a diet packed in a paper cup $(3 \mathrm{~cm})$, moistened cotton, fan-folded paper, and artificial shelter consisting of semitransparent polypropylene straws $(10 \mathrm{~cm} \times 8 \mathrm{~mm}$ ) were added, sealed at one end with cotton (Pasini et al., 2007; Silva, 2019). The diet consisted of 35\% cat food, $27 \%$ wheat bran, $23 \%$ beer yeast, $14 \%$ milk powder, $0.5 \%$ nipagin, and $0.5 \%$ sorbic acid mixed in a blender until it becomes a homogeneous powder mixture (Cruz, 2009). The rearing maintenance was carried out weekly, and the straws containing earwig eggs were removed and kept in glass pots $(15 \times 10 \mathrm{~cm})$ containing diet for the females until the nymphs hatch. Subsequently, the females returned for breeding, and the nymphs were transferred to plastic containers $(37 \times 27 \mathrm{~cm})$ containing folding paper, moistened cotton and artificial diet. The eggs of Spodoptera frugiperda previously inactivated by low temperatures were obtained from the rearing and maintenance methodology described by Mendes et al. (2011).

\subsection{Puccinia polysora}

P. polysora uredospores from the fungi collection of the Phytopathology laboratory of Embrapa Milho e Sorgo, Sete Lagoas, MG, was used to obtain the initial inoculum. In a greenhouse, the uredospores were multiplied in maize plants of the BRS1010 cultivar susceptible to Southern rust. In the laboratory, the uredospore multiplication was made in a $500 \mathrm{~mL}$ Erlenmeyer flask. Part of the initial inoculum was diluted in a surfactant solution (Tween 80) and stirred for three minutes to homogenize the mass of uredospores. Then, the inoculum concentration was adjusted to $10^{4}$ uredospores / $\mathrm{mL}$ and applied to maize plants using a $500 \mathrm{~mL}$ hand sprayer 25 days after sowing. The plants were kept in a greenhouse in $5 \mathrm{~kg}$ pots containing soil and commercial substrate until the uredospores were collected. After 15 to 20 days, 
the Southern rust symptoms, characterized by circular to elongated pustules and a light to dark brown color, were observed on the leaf surface. The uredospores were collected, placed in Eppendorf tubes, and kept at a temperature of $10{ }^{\circ} \mathrm{C}$ until use in bioassays.

\subsection{Pollen collection}

The pollen grains were collected from plants of commercial maize hybrids grown in 2018-2019 season at the Center for Scientific and Technological Development in Agriculture of the Federal University of Lavras, Fazenda Muquém, located in the municipality of Lavras - MG (44 58' 48.7" west longitude and $21^{\circ} 12^{\prime} 16.7^{\prime \prime}$ south latitude; altitude $=951 \mathrm{~m}$ ).

\subsection{Does exclusive feeding with one food resource in maize plants affect the nymph's survival?}

Doru luteipes nymphs (up to 48 hours old) were individualized in plastic containers $(500 \mathrm{~mL})$ with artificial shelter formed by semitransparent polypropylene straw (10 cm long and $0.8 \mathrm{~cm}$ in diameter), sealed at one end with cotton, moistened cotton, and paper cup ( $3 \mathrm{~cm})$ as a container for food. The containers were sealed with voile fabric and kept under controlled conditions at $25 \pm$ $2{ }^{\circ} \mathrm{C}, 70 \pm 10 \% \mathrm{RH}$, and $12 \mathrm{~h}$ photophase. The treatments consisted of five food sources 1 - uredospores of P. polysora; 2-S. frugiperda eggs; 3 - uredospores of $P$. polysora + eggs of S. frugiperda; 4- corn pollen, and 5- artificial diet (control). Twenty-five repetitions per food source were used, and each individual was considered as one repetition. The survival assessment was carried out until the adult stage was reached.

\subsection{Does D. luteipes' food preference vary between nymphs and adults, and feeding times?}

In order to determine the food preference among various food sources commonly found in maize, nymphs, and adults of $D$. luteipes were used in a chance of choice test with 1- eggs of $S$. frugiperda, 2- corn pollen, 3- uredospores of $P$. polysora, and 4- artificial diet. Nymphs and adults of $D$. luteipes fasting for 24 and 48 hours were kept in glass test tubes, with cylindrical bottom, containing moistened cotton to evaluate the insect's food choice. After each starvation period, the insect was released in the center of a plastic container $(500 \mathrm{~mL})$ with the four food sources in paper cups $(3 \mathrm{~cm}$ ) arranged equidistantly from each other. For 10 minutes, the chosen food and the feeding time were determined using a stopwatch. The tests were performed during the daytime, between $1 \mathrm{pm}$ and $5 \mathrm{pm}$ and at night, between $7 \mathrm{pm}$ and $10 \mathrm{pm}$. The biossay was replicate 20 times, and one individual of $D$. luteipes was used in each replicate.

\subsection{Statistics}

The nymph survival data were submitted to KaplanMeier analysis using the Software R version 3.6.0 (R Core Team, 2019). Data regarding the duration of the early developmental stage and percentage of nymph survival concerning the assumptions of normality of errors and homogeneity of variances were subjected to analysis of variance (ANOVA) and the means compared by the Tukey test at $5 \%$ probability. The Fisher exact test was used for association data between the food choice according to the developmental stage, and for the case in which the frequency was less than five. To verify differences between every two combinations, the Chi-Square post hoc test was used at a significance level of 0.05 , and the Kruskal-Wallis non-parametric test was performed $(p<0.05)$ was performed to compare the chosen feeding time and food choice.

\section{Results}

The logrank test shows that there is a significant difference between at least two survival curves $(\mathrm{P}<0.001)$. Then, a multiple comparison analysis based on the logrank test was performed to verify the existence of a difference between the treatments (Figure 1).

The $S$. frugiperda egg-based diet provided the lowest survival rate $(\mathrm{P}<0.001)$, and consequently, the number of nymphs developing into adults was significantly lower compared to nymphs fed with the other three food sources (Figure 1, Table 1).

The exclusive feeding on corn pollen led to a lower number of surviving nymphs compared to those fed with the artificial diet $(\mathrm{P}=0.00379)$, uredospores $(\mathrm{P}=0.00169)$, and eggs + uredospores $(P=0.00169)$ (Figure 1, Table 1$)$.

The monotrophic diet with $P$. polysora uredospores extended the duration of the instar stages and consequently increased the period of the early stage. In general, the survival was diminished for nymphs that exclusively fed on eggs, uredospores, and pollen (Table 1 ).

In the diet composed exclusively of $S$. frugiperda eggs, the survival was low, with only $8 \%$ of insects reaching the adult phase (Table 1 ). However, the combination of S. frugiperda eggs + P. polysora uredospores contributed to maintaining the survival of $D$. luteipes in $58 \%$, which was similar to the control treatment (Table 1).

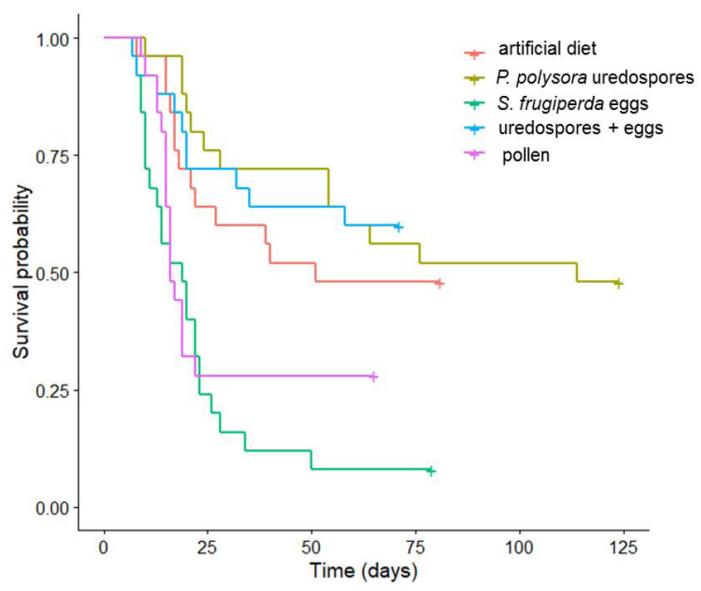

Figure 1. Survival curves based on Kaplan-Meier estimates nonparametric method for immature stages of Doru luteipes as a food-sources function. 
Table 1. Average duration $( \pm$ SE) in days and percentage of immature survival Doru luteipes as a food-sources function.

\begin{tabular}{|c|c|c|c|c|c|}
\hline & \multicolumn{5}{|c|}{ Food sources } \\
\hline & S. frugiperda & P. polysora & $\begin{array}{l}\text { P. polysora + } \\
\text { S. frugiperda }\end{array}$ & Pollen & Control \\
\hline \multicolumn{6}{|c|}{ Duration (days) } \\
\hline $1^{\text {st }}$ instar & $9.3 \pm 1.2 \mathbf{b}^{*}$ & $15.0 \pm 1.9 \mathbf{a}$ & $7.4 \pm 0.7 \mathbf{b}$ & $5.6 \pm 0.3 \mathbf{b}$ & $6.3 \pm 0.3 \mathbf{b}$ \\
\hline $2^{\text {nd }}$ instar & $7.9 \pm 0.0 \mathbf{b}$ & $19.0 \pm 2.2 \mathbf{a}$ & $8.8 \pm 0.9$ b & $8.0 \pm 0.2 \mathbf{b}$ & $8.5 \pm 1.2 \mathbf{b}$ \\
\hline $3^{\text {rd }}$ instar & $15.3 \pm 7.4 \mathbf{a}$ & $14.5 \pm 2.7 \mathbf{a b}$ & $8.1 \pm 0.4$ bc & $6.4 \pm 0.2$ c & $7.0 \pm 0.4$ bc \\
\hline $4^{\text {th }}$ instar & $8.0 \pm 5.0 \mathbf{a}$ & $10.5 \pm 2.3 \mathbf{a}$ & $9.2 \pm 0.6 \mathbf{a}$ & $10.0 \pm 0.5 \mathbf{a}$ & $8.4 \pm 0.4 \mathbf{a}$ \\
\hline Total & $39.5 \pm 1.9 \mathbf{b}$ & $59.0 \pm 1.74 \mathbf{a}$ & $33.5 \pm 0.0 \mathbf{b}$ & $33.2 \pm 1.0 \mathbf{b}$ & $30.2 \pm 0.5 \mathbf{b}$ \\
\hline \multicolumn{6}{|c|}{ Survival rate (\%) } \\
\hline $1^{\text {st }}$ instar & $75.0 \mathbf{b}$ & $85.0 \mathbf{a b}$ & $95.8 \mathbf{a}$ & $95.8 \mathbf{a}$ & $95.8 \mathbf{a}$ \\
\hline $2^{\text {nd }}$ instar & $25.0 \mathrm{c}$ & $58.3 \mathbf{b}$ & $75.0 \mathbf{a}$ & $83.3 \mathbf{a}$ & $79.2 \mathbf{a}$ \\
\hline $3^{\text {rd }}$ instar & $12.5 \mathrm{c}$ & $45.8 \mathbf{b}$ & $62.5 \mathbf{a}$ & $20.8 \mathrm{c}$ & $62.5 \mathbf{a}$ \\
\hline $4^{\text {th }}$ instar & $8.3 \mathrm{c}$ & $37.5 \mathbf{b}$ & $58.3 \mathbf{a}$ & $20.8 \mathrm{c}$ & $58.3 \mathbf{a}$ \\
\hline
\end{tabular}

${ }^{*}$ Averages followed by the same letter on the line do not differ by Tukey's test at $5 \%$ probability.

Table 2. Percentage of choice of nymphs and adults of Doru luteipes exposed to different food sources during the night with 24 and 48 hours of starvation.

\begin{tabular}{|c|c|c|c|c|c|c|c|c|c|c|}
\hline \multirow{3}{*}{ Food Sources } & \multicolumn{10}{|c|}{ Developmental Stage } \\
\hline & \multicolumn{2}{|c|}{$1^{\circ}$ instar } & \multicolumn{2}{|c|}{$2^{\circ}$ instar } & \multicolumn{2}{|c|}{$3^{\circ}$ instar } & \multicolumn{2}{|c|}{$4^{\circ}$ instar } & \multicolumn{2}{|c|}{ Adult } \\
\hline & $24 \mathrm{~h}$ & $48 h$ & $24 \mathrm{~h}$ & $48 \mathrm{~h}$ & $24 \mathrm{~h}$ & $48 \mathrm{~h}$ & $24 \mathrm{~h}$ & $48 \mathrm{~h}$ & $24 \mathrm{~h}$ & $48 h$ \\
\hline Control & 19.0 & 21.7 & 23.8 & 13.0 & 0.0 & 21.7 & 14.3 & 13.0 & 42.8 & 30.4 \\
\hline P. polysora & 24.3 & 20.0 & 13.5 & 32.0 & 21.6 & 16.0 & 21.6 & 12.0 & 18.9 & 20.0 \\
\hline S. frugiperda & 18.2 & 30.7 & 18.2 & 30.1 & 27.3 & 0.0 & 9.1 & 30.0 & 27.3 & 7.7 \\
\hline Pollen & 16.2 & 15.4 & 25.8 & 12.8 & 29.0 & 28.2 & 25.8 & 25.6 & 3.2 & 17.9 \\
\hline
\end{tabular}

Table 3. P-values of post hoc of test exact fisher of the comparison between combinations of two food sources in the food preference test performed at night with nymphs and adults of Doru luteipes starved for 24 hours.

\begin{tabular}{lccc}
\hline \multicolumn{1}{c}{ Food Sources } & P. polysora & S. frugiperda & Pollen \\
\hline Control & 0.1777 & 0.828 & $0.0054^{*}$ \\
P. polysora & - & 0.8710 & 0.2828 \\
S. frugiperda & - & - & 0.2828 \\
\hline
\end{tabular}

${ }^{*} \mathrm{p} \leq 0.05$.

The exclusive diet with maize pollen by the first and second instars of $D$. luteipes provided survival greater than $80 \%$. However, after the 3rd instar there was a marked reduction of approximately $20 \%$ in the insect development.

It was observed an association between food resources and developmental stage $(P=0.03)$, when the individuals were fasted for 24 hours and exposed to the food sources only at night. The contrast between the artificial vs. natural diet features pollen $(P=0.0054)$ resulted in a higher percentage of choices for both nymphs and adults of $D$. luteipes by one of these sources (Tables 2 and 3). Also, the time spent during feeding was significant for second instar nymphs $(\mathrm{P}=0.02604)$. When contrasting the diet vs. uredospores $(\mathrm{P}=0.0223)$ and diet vs. pollen (0.0292), the nymphs of the second instar ate more time in the diet (Figure 2C), of which they had previous experience. There was no dependence between the chosen food and the stage of $D$. luteipes $(P=0.25)$, when the fasting period was $48 \mathrm{~h}$ and the food test was performed at night. Thus, there was only a difference in the feeding time of adults in relation to the combination of diet vs. pollen, and they preferred to feed on pollen ( $P=0.0083$ ), even without previous experience of feeding (Figure 2J).

In the tests performed during the day, the results for fasting for 24 hours $(P=0.66)$ and 48 hours $(0.06)$, there was no dependence between the food source and stage of development (data not shown). 


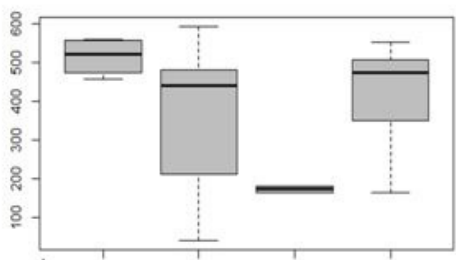

A

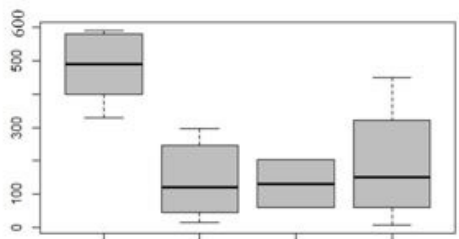

C*
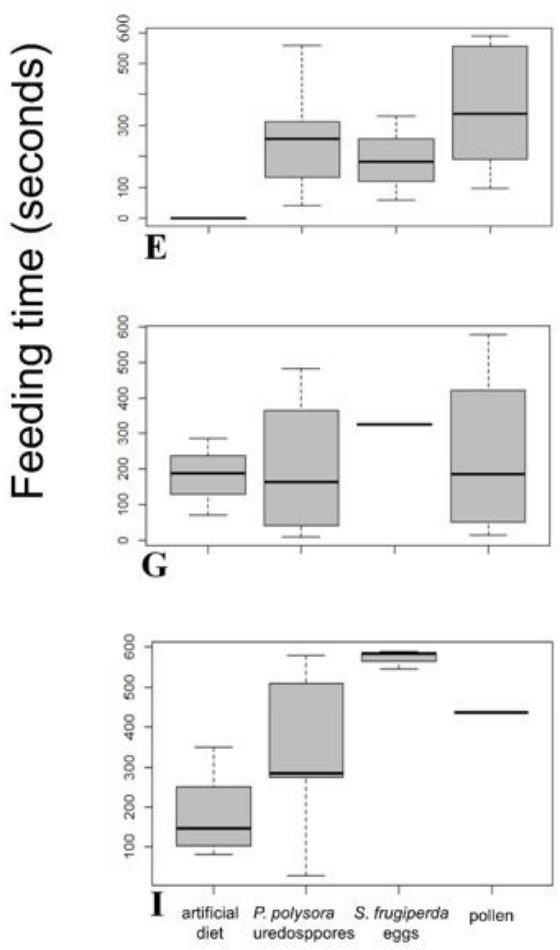

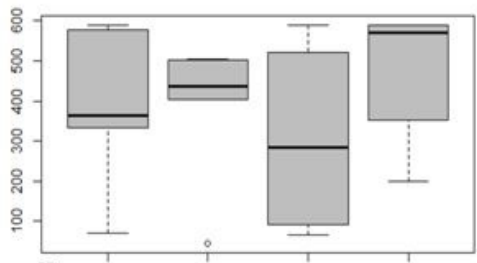

$\mathbf{B}$

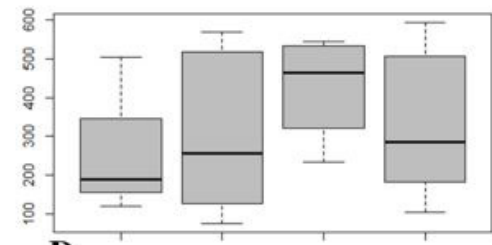

D
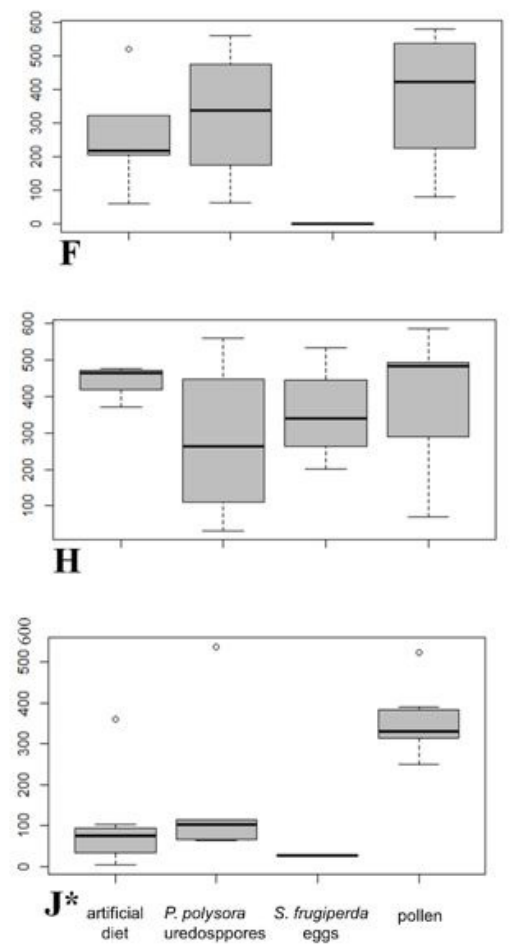

Figure 2. Night feeding time of Doru luteipes with different food sources after 24 and 48 hours starvation. (A) first instar nymphs and 24 hour starvation ( $p=0.16)$; (B) first instar nymphs and $48 \mathrm{~h}$ starvation $(\mathrm{p}=0.07)$; (C) second instar nymphs and $24 \mathrm{~h}$ starvation $\left(p=0.02^{*}\right)$; (D) second instar nymphs and 48 h starvation ( $\left.p=0.60\right)$; (E) third instar nymphs and 24 h starvation $(p=0.17) ;(F)$ thirdinstar nymphs and $48 \mathrm{~h}$ starvation ( $\mathrm{p}=0.25)$; $(\mathrm{G})$ fourth-instar nymphs and $24 \mathrm{~h}$ starvation $(\mathrm{p}=0.84)$; $(\mathrm{H})$ fourth-instar nymphs and $48 \mathrm{~h}$ starvation ( $\mathrm{p}=0.67)$; (I) adult and $24 \mathrm{~h}$ starvation $(\mathrm{p}=0.14)$, ( $)$ adult and $48 \mathrm{~h}$ starvation $\left(\mathrm{p}=0.02^{*}\right)$.

\section{Discussion}

Our findings showed that omnivorous habit plays a fundamental role in the survival and maintenance of $D$. luteipes. However, as an omnivorous insect, the consumption of a single food source can influence the duration of both instar and nymphal stages, as demonstrated by Marucci et al. (2019). These authors observed a low survival of $D$. luteipes under exclusive feeding of $S$. frugiperda eggs instead of corn pollen, while the dietary combination of pollen plus aphid resulted in twice the insect survival rate.

Nevertheless, Pasini et al. (2007) reported a different result demonstrated by the survival rate of $75 \%$ of $D$. luteipes fed exclusively with eggs of $S$. frugiperda. Interestingly, the combined diet consisting of eggs of S. frugiperda plus $P$. polysora uredospores increased the survival of $D$. luteipes without altering the total duration of its young phase. This result was similar to that of using the artificial diet, which 
is a food source considered appropriate for maintaining D. luteipes in the laboratory. This finding highlights the need for a diversified diet and reinforces the omnivorous habit of $D$. luteipes. From this perspective, the known voracity of D. luteipes (Souza et al., 2021; Romero-Sueldo and Virla, 2017), suggests that this predator has a great potential to reduce prey and fungal pathogens in maize fields. Also, in the maize reproductive stage, the pollen functions as an essential factor attracting and maintaining $D$. luteipes in the maize cultures.

To understand the role of $D$. luteipes as a predator with dual function (i.e. entomophagous and mycophagous), we determined the food preference of this insect in a situation of concomitant occurrence of pollen, eggs, and uredospores. As a nocturnal predator, regardless of the fasting time, it was possible to verify an association between the choice of different tested food sources and the development stages only at night, with pollen preference over control, both by nymphs and adults.

In the tests performed during the day, even after $48 \mathrm{~h}$ of fasting, it was not possible to determine the feeding preference of nymphs and adults of the predator. According to Naranjo-Guevara et al. (2017), the consumption of $S$. frugiperda by females of $D$. luteipes occurred between $7 \mathrm{pm}$ and $9 \mathrm{pm}$, and in the daytime, there was no consumption even after 48 hours of fasting. These results indicate that $D$. luteipes forages exclusively at night regardless of the fasting period.

The members of the order Dermaptera are known to live in a dark and damp shelter, mainly in aggregation (Hehar et al., 2008; Campos et al., 2011). They have a tigmotactile habit (Jarvis et al., 2005) seeking direct contact with cospecific and the maize plants, which provide an ideal shelter for the insect during the day. At night, adults of $D$. luteipes are more active and spend more time feeding on pollen. In this sense, the maize pollen represents a nutritious food source, rich in carbohydrates, proteins, amino acids, lipids, vitamins, minerals, and trace elements (Malerbo-Souza, 2011).

Food sources such as pollen, sap, nectar, and fungi are a crucial alternative diet to some predatory insects (Pemberton and Vandenberg, 1993; Lundgren, 2009). However, the time allocated by omnivorous predators to consume prey vs. plant resources such as pollen, directly influence their effectiveness as biocontrol agents (Schuldiner-Harpaz et al., 2016). The specific benefits resulting from alternative-food consumption will depend on the development stage of the predators, as well as on the nutritional quality of the food eaten and on how the combination of food diets meets their nutritional needs at the specific stage of the development (Goeriz Pearson et al., 2011). This observation highlights a complex system with several simultaneous interactions where one action interferes with the performance of the other, along with the direct influencing factors such as age, sex, and environmental conditions (Simpson and Raubenheimer, 1995).

In our work, the exposure of $D$. luteipes to a single food source (i.e. eggs of $S$. frugiperda, uredospores of $P$. polysora, or maize pollen) directly interfered in the nymphal development as reflected in the number of emerged adults. Thus, any nutritional deficiency occurring in the early stages of development significantly increases the mortality and compromises the reproductive parameters of the predators (Hodek et al., 2012). This result indicates that such foods can act as complementary sources of nutrients but not exclusive, during the active growth phase of $D$. luteipes. Although $D$. luteipes has completed its developmental cycle by feeding exclusively on uredospores, this food should be considered only as a complementary food, since it prolongs the duration of the young phase and reduces the survival rate of nymphs. Marucci et al. (2019) observed a similar result when $D$. luteipes was fed exclusively with pollen. Although pollen is an essential nutrient for the reproductive phase of $D$. luteipes, it is detrimental during the nymph development stage. The gain due to complementary feeding of omnivorous predators can vary according to the development stage, thus justifying different food choices between nymphs and adults (Vankosky and VanLaerhoven, 2015). Females of Forficula senegalensis (Audinet-Serville, 1838; Dermaptera: Forficulidae), for example, require a rich diet composed of pollen or animal prey in order to oviposit. Diets based on pollen or eggs and larvae of Lepidoptera constitute a better quality food for $F$. senegalensis, which guarantee a high percentage of fertile females, and allow some females to continue laying eggs (Boukary et al., 1998).

Although the effects of omnivory are still poorly elucidated, they open a new perspective toward understanding the real role of $D$. luteipes as a biological control agent and exploring this relationship to minimize the effects of pests and fungal diseases in maize crops. Thus, the omnivorous and mycophagous habit of $D$. luteipes can be advantageous in maize production areas since they allow the survival of a biological control agent with a diversified diet based on lepidopteran eggs, fungal structures, and maize pollen. However, some natural features of $D$. luteipes, such as its subsocial behavior, and the direct contact with plants and cospecifics, may represent a risk for the maize crop. Considering that the uredospores are only partially destroyed in the digestive tract of $D$. luteipes (Silva et al., 2022), thus the predator can function as an agent of dispersion of the pathogen spreading fungal diseases throughout the maize crop.

Future studies should address the direct contact of $D$. luteipes with plants and conspecifics. Understanding this trophic behavior of $D$. luteipes is relevant to determine the real contribution of this important predator in the biological control of pests and diseases in maize culture.

\section{Conclusions}

The duration of the nymphal period, as well as the survival of $D$. luteipes, are affected by the food resource available in maize plants with better positive results for the combination of uredospores of $P$. polysora and eggs of S. frugiperda.

Only at night, nymphs, and adults of $D$. luteipes, choose and spend more time feeding on pollen concerning the other food sources available in the maize plants. 


\section{References}

BACCI, L., PICANÇO, M.C., GUSMÃO, M.R., CRESPO, A.L.B. and PEREIRA, E.J.G., 2001. Seletividade de Inseticidas a Brevicoryne brassicae (L.) (Hemiptera: Aphididae) e ao Predador Doru luteipes (Scudder) (Dermaptera: Forficulidae). Neotropical Entomology, vol. 30, no. 4, pp. 707-713. http://dx.doi.org/10.1590/S1519566X2001000400028.

BOUKARY, I.B., GINGRAS, J. and TOURNEUR, J.C., 1998. Influence of diet on oviposition and survival of Forficula sengalensis Serville (Dermaptera: forficulidae). Canadian Entomologist, vol. 130, no. 2, pp. 163-167. http://dx.doi.org/10.4039/Ent130163-2.

CAMPOS, M.R., PICANÇO, M.C., MARTINS, J.C., TOMAZ, A.C. and GUEDES, R.N.C., 2011. Insecticide selectivity and behavioral response of the earwig Doru luteipes. Crop Protection, vol. 30, no. 12, pp. 1535-1540. http://dx.doi.org/10.1016/j. cropro.2011.08.013.

CASELA, C.R. and FERREIRA, A.S., 2002. Variability in isolates of Puccinia polysora in Brazil. Fitopatologia Brasileira, vol. 27, no. 4, pp. 414-416. http://dx.doi.org/10.1590/S010041582002000400015 .

CHEN, G., ZHANG, R.R., LIU, Y. and SUN, W.B., 2014. Spore Dispersal of Fetid Lysurus mokusin by Feces of Mycophagous Insects. Journal of Chemical Ecology, vol. 40, no. 8, pp. 893-899. http:// dx.doi.org/10.1007/s10886-014-0481-6. PMid:25064696.

COLL, M., 1996. Feeding and ovipositing on plants by an omnivorous insect predator. Oecologia, vol. 105, no. 2, pp. 214-220. http:// dx.doi.org/10.1007/BF00328549. PMid:28307085.

CRUZ, I., 2009. Métodos de criação de agentes entomófagos de Spodoptera frugiperda (J. E. Smith). In: V. H. P. BUENO, ed. Controle biológico de pragas: produção massal e controle de qualidade. 2. ed. Lavras: UFLA, pp. 237-275.

CRUZ, I., 2007. Controle biológico de pragas na cultura de milho para produção de conservas (minimilho), por meio de parasitóides e predadores. Circular Técnica Embrapa, vol. 91, pp. 1-16.

DUDIENAS, C., FANTIN, G.M., DUARTE, A.P., TICELLI, M., BÁRBARO, I.M., FREITAS, R.S., LEÃO, P.C.L., CAZENTINI FILHO, G., BOLONHEZI, D. and PÂNTANO, A.P., 2013. Severidade de ferrugem-polissora em cultivares de milho e seu efeito na produtividade. Summa Phytopathologica, vol. 39, no. 1, pp. 16-23. http://dx.doi. org/10.1590/S0100-54052013000100003.

GOERIZ PEARSON, R.E., BEHMER, S.T., GRUNER, D.S. and DENNO, R.F., 2011. Effects of diet quality on performance and nutrient regulation in an omnivorous katydid. Ecological Entomology, vol. 36, no. 4, pp. 471-479. http://dx.doi.org/10.1111/j.13652311.2011.01290.x.

HEHAR, G., GRIES, R. and GRIES, G., 2008. Re-analysis of pheromonemediated aggregation behaviour of European earwigs. Canadian Entomologist, vol. 140, no. 6, pp. 674-681. http://dx.doi. org/10.4039/n08-026.

HODEK, I., VAN EMDEN, H.F., HONEK, A. and SANTOS, C.A., 2012. Ecology of Coccinellidae. Dordrecht: Wiley-Blackwell, 600 p.

JARVIS, K.J., HAAS, F. and WHITING, M.F., 2005. Phylogeny of earwigs (Insecta: Dermaptera) based on molecular and morphological evidence: reconsidering the classification of Dermaptera. Systematic Entomology, vol. 30, no. 3, pp. 442-453. http://dx.doi. $\operatorname{org} / 10.1111 / \mathrm{j} .1365-3113.2004 .00276 . x$.

LAMB, R.J. and WELLINGTON, W.G., 1975. Life history and population characteristics of the european earwig, Forficula auricularia (Dermaptera: Forficulidae), at Vancouver, Bristish Columbia. Canadian Entomologist, vol. 107, no. 8, pp. 819-824. http:// dx.doi.org/10.4039/Ent107819-8.
LUNDGREN, J.G., 2009. Nutritional aspects of non-prey foods in the life histories of predaceous Coccinellidae. Biological Control, vol. 51, no. 2, pp. 294-305. http://dx.doi.org/10.1016/j. biocontrol.2009.05.016.

MALERBO-SOUZA, D.T., 2011. The corn pollen as a food source for honeybees. Acta Scientiarum. Agronomy, vol. 33, no. 4, pp. 701-704. http://dx.doi.org/10.4025/actasciagron.v33i4.10553.

MARUCCI, R.C., SOUZA, I.L., SILVA, L.O., AUAD, A.M. and MENDES, S.M., 2019. Pollen as a component of the diet of Doru luteipes (Scudder, 1876)(Dermaptera: forficulidade). Brazilian Journal of Biology = Revista Brasileira de Biologia, vol. 79, no. 4, pp. 584-588. http://dx.doi.org/10.1590/1519-6984.184072. PMid:30365637.

MENDES, S.M., BOREGAS, K.G.B., LOPES, M.E., WAQUIL, M.S. and WAQUIL, J.M., 2011. Respostas da lagarta-do-cartucho a milho geneticamente modificado expressando a toxina Cry $1 \mathrm{~A}(\mathrm{~b})$. Pesquisa Agropecuária Brasileira, vol. 46, no. 3, pp. 239-244. http://dx.doi.org/10.1590/S0100-204X2011000300003.

NARANJO-GUEVARA, N., PEÑAFLOR, M.F.G.V., CABEZAS-GUERRERO, M.F. and BENTO, J.M.S., 2017. Nocturnal herbivore-induced plant volatiles attract the generalist predatory earwig Doru luteipes Scudder. Naturwissenschaften, vol. 104, no. 9-10, pp. 497-507. http://dx.doi.org/10.1007/s00114-017-1498-9. PMid:28871442.

PASINI, A., PARRA, J.R.P. and LOPES, J.M., 2007. Dieta artificial para criação de Doru luteipes (Scudder) (Dermaptera: Forficulidae), predador da lagarta-do-cartucho do milho, Spodoptera frugiperda (J.E. Smith) (Lepidoptera: Noctuidae). Neotropical Entomology, vol. 36, no. 2, pp. 308-311. http://dx.doi.org/10.1590/S1519566X2007000200020. PMid:17607467.

PAULA, D.P., LINARD, B., CRAMPTON-PLATT, A., SRIVATHSAN, A., TIMMERMANS, M.J.T.N., SUJII, E.R., PIRES, C.S.S., SOUZA, L.M., ANDOW, D.A. and VOGLER, A.P., 2016. Uncovering Trophic Interactions in Arthropod Predators through DNA ShotgunSequencing of Gut Contents. PLoS One, vol. 11, no. 9, pp. e0161841. http://dx.doi.org/10.1371/journal.pone.0161841. PMid:27622637.

PEMBERTON, R.W. and VANDENBERG, R.J., 1993. Extrafloral nectar feeding by ladybird beetles (Coleoptera: coccinellidae). Proceedings of the Entomological Society of Washington, vol. 95, no. 2, pp. 139-151.

R CORE TEAM, 2019 [viewed 23 September 2020]. R: a language and environment for statistical computing [online]. Vienna: $\mathrm{R}$ Foundation for Statistical Computing. Available from: http:// www.R-project.org/

ROMERO-SUELDO, G.M. and VIRLA, E.G., 2017. Datos biológicos de Doru luteipes (Dermaptera: Forficulidae) en plantaciones de caña de azúcar y consumo de huevos de Diatraea saccharalis (Lepidoptera: Crambidae) en condiciones de laboratorio. Revista de la Sociedad Entomológica Argentina, vol. 68, no. 3-4, pp. 359-363.

ROMERO-SUELDO, G.M., BRUZZONE, O.A. and VIRLA, E.G., 2010. Characterization of the earwig, Doru lineare, as a predator of larvae of the Fall Armyworm, Spodoptera frugiperda: a functional response study. Journal of Insect Science, vol. 10, no. 38, pp. 38. http://dx.doi.org/10.1673/031.010.3801. PMid:20575739.

ROMERO-SUELDO, G.M., DODE, M. and VIRLA, E.G., 2014. Depredación de Doru luteipes y D. lineare (Dermaptera: Forficulidae) sobre Rhopalosiphum maidis (Hemiptera: Aphididae) en condiciones de laboratorio. Acta Zoológica Lilloana, vol. 58, no. 1, pp. 73-79.

SCHULDINER-HARPAZ, T. and COLL, M., 2017. Estimating the effect of plant-provided food supplements on pest consumption by omnivorous predators: lessons from two coccinellid beetles. Pest Management Science, vol. 73, no. 5, pp. 976-983. http:// dx.doi.org/10.1002/ps.4410. PMid:27470503. 
SCHULDINER-HARPAZ, T., COLL, M. and WEINTRAUB, P.G., 2016. Prey and pollen food choice depends on previous diet in an omnivorous predatory mite. Environmental Entomology, vol. 45, no. 4, pp. 995-998. http://dx.doi.org/10.1093/ee/nvw063. PMid:27271945.

SHURTLEFF, M.C., 1992. Compendium of corn diseases. 2nd ed. St. Paul: American Phytopathological Press, 105 p.

SILVA, D.D., MENDES, S.M., PARREIRA, D.F., PACHECO, R.C., MARUCCI, R.C., COTA, L.V., COSTA, R.V. and FIGUEIREDO, J.E.F., 2022. Fungivory: a new and complex ecological function of Doru luteipes. Brazilian Journal of Biology $=$ Revista Brasileira de Biologia, vol. 82, pp. e238763. http://dx.doi.org/10.1590/15196984.238763.

SILVA, L.P., 2019. Compatibilidade da combinação de Doru luteipes (Dermaptera, Forficulidae) e Orius insidiosus (Hemiptera, Anthocoridae) para regulação de tripes-praga (Thysanoptera, Thripidae). Lavras: Universidade Federal de Lavras, 52 p. Dissertação de Mestrado em Entomologia Agrícola.

SIMPSON, S.J. and RAUBENHEIMER, D., 1995. The geometric analysis of feeding and nutrition: a user's guide. Journal of
Insect Physiology, vol. 41, no. 7, pp. 545-553. http://dx.doi. org/10.1016/0022-1910(95)00006-G.

SOUZA, C.S.F., REDOAN, A.C., RIBEIRO, C., CRUZ, I., CARVALHO, G.A. and MENDES, S.M., 2019 [viewed 23 September 2020 ]. Controle biológico: qual espécie de tesourinha consome mais lagartas e pode ser menos sensivel à exposição a inseticidas? [online]. Sete Lagoas: Embrapa Milho e Sorgo, 23 p. Boletim de Pesquisa e Desenvolvimento, no. 188. Available from: http://www.infoteca. cnptia.embrapa.br/infoteca/handle/doc/1111610

SOUZA, C.S.F., SILVEIRA, L.C.P., SOUZA, B.H.S., NASCIMENTO, P.T., DAMASCENO, N.C.R. and MENDES, S.M., 2021. Efficiency of biological control for fall armyworm resistant to the protein Cry1F. Brazilian Journal of Biology = Revista Brasileira de Biologia, vol. 81, no. 1, pp. 154-163. http://dx.doi.org/10.1590/15196984.224774

VANKOSKY, M.A. and VANLAERHOVEN, S.L., 2015. Plant and prey quality interact to influence the foraging behaviour of an omnivorous insect, Dicyphus hesperus. Animal Behaviour, vol. 108, pp. 109-116. http://dx.doi.org/10.1016/j. anbehav.2015.07.019. 